\title{
Enormity of iron deficiency anaemia and haematological indices in Primary and secondary school going children in central rural Gujarat, India
}

\author{
Research Article
}

\section{Aboli Patil1*, Rajanish Meti1, Swapnil CR1, Mahesh Parappagoudra1, Parikshit Kumar ${ }^{1}$}

1. Associate Professor, Department of Kaumarbhritya, Dr.D.Y.Patil college of Ayurved \& Research centre, Pimpri, Pune. Ph.D Scholar, Department of Kaumarbhritya, Parul Institute of Ayurved, Parul University, Limda, Vadodara, Gujarat.

2. Professor and HOD, Department of Kaumarbhritya, BVVS Ayurvedic Medical college, Bagalkot, Karnataka.

3. Associate Professor, Department of Kaumarbhritya, Parul Institute of Ayurved, Parul University, Limda, Vadodara,Gujarat. 4. Assistant Professor, Dept. of Panchakarma, Parul Institute of Ayurved, Parul University, Limda, Vadodara, Gujarat.

5. Assistant Professor, Department of Kaumarbhritya, WTM Ayurvedic College, Amroha, Uttar Pradesh, India.

\begin{abstract}
Anemia is one of the associated and underlying health conditions observed in large number of school going children of rural India. National Family Health Survey (NHFS) data published by Government of India indicates increased prevalence of anaemia in children of rural India. In the present study, children of government school of the Waghodia tehsil, Vadodara district Gujarat were surveyed. A cross sectional study was conducted to survey 500 children of either gender according to WHO gradation as normal range $(12.6 \pm 0.54 \mathrm{gm} / \mathrm{dl})$; mild anemia $(11.01 \pm$ $0.58 \mathrm{gm} / \mathrm{dl})$ and moderate anemia $(9.11 \pm 0.3 \mathrm{gm} / \mathrm{dl})$. Observations indicated that, $20.6 \%, 74.8 \%$ and $4.6 \%$ children were in normal or above normal range, mild anemia and moderate anemia respectively. Overall $79.4 \%$ of children have anemia. It reveals the escalating magnitude of prevalence of IDA in rural Gujarat. Prevalence is more in 9-11 age group (56\%). Gender wise distribution shows mild and moderate anemia in $305(80.9 \%)$ and $14(3.7 \%)$ respectively amongst 377 male children; whereas mild anemia and moderate anemia in $305(80.9 \%)$ and $14(3.7 \%)$ respectively amongst 123 female children. In nutshell, prevalence of anemia is prominent in children of age group in different rural parts of Gujarat.
\end{abstract}

Key Words: Anemia, Survey study, School going children, Gujarat, Limda.

\section{Introduction}

The nutritional status is a crucial factor which defines health and well being of a child. Nutritional deficiency anemia is a major public health problem in children and pregnant women especially in developing countries including India. Anaemia is never a defined disease, however an indication of underlying pathological process or disease of various aetiologies like worm infestations, malnutrition etc. As a consequence of these various factor iron deficiency determines prime nutritional deficiency health problem.

The magnitude of the problem is high among both urban and rural populations. As the fact mild to moderate forms of anemia are not detected by the parents and it goes unnoticed and untreated until clinician or pediatrician identifies the condition when the child is brought to him for any other health problem. Rural parents or the lower socioeconomic population

* Corresponding Author:

\section{Aboli Patil}

Associate Professor,

Department of Kaumarbhritya,

Dr. D.Y.Patil college of Ayurved \& Research Centre, Pimpri, Pune. India.

Email Id: drabolipatil@gmail.com does not take their children for routine health checkups, even if these children are taken for the routine immunization clinical examination missed out.

Anemia is a condition that is marked by low level of hemoglobin in the blood. Iron is a main component of hemoglobin and iron deficiency is estimated to be responsible for half of all anemia globally (3 NFHS-4 2015-16 P -298)(1).As per NHFS survey 2015-16 children in the age group of 6-59 months, $59 \%$ of children had some degree of anemia (hemoglobin levels below $11.0 \mathrm{~g} / \mathrm{dl}$ ), 28\% had mild anemia(2).The trend of anemia in year 2005-2006 had reduced from $70 \%$ to $59 \%$ but continued at higher side among rural children. In Gujarat prevalence of any anemia in children of age 6 to 59 months was $62.6 \%$, (NHFS 2015-16 P 322 TABLE 10.13 )(3). Anemia in young children can result into impaired cognitive abilities language development motor and behavioral development and increased risk of morbidity from infectious diseases.

So the early detection through screening and surveillance, preventive measures and timely management of IDA in children is very essential to ensure wellbeing of all age group children. Different cross-sectional survey studies found the base in such mass screening program. 
Cross-sectional studies (also known as Crosssectional analysis) form a class of research methods that involve observation of all of a population, or a representative subset, at a defined time. They differ from case-control studies in that they aim to provide data on the entire population under study.

These studies described certain feature of the population, such as prevalence of an illness, or they may support inferences of cause and effect. In addition, cross-sectional studies involve data collected at a defined time. They are often assessed the prevalence of acute or chronic conditions, or to answer questions about the causes of disease or the results of medical intervention. Cross-sectional studies may involve special data collection, including questions about the past, but they often rely on data originally collected for other purposes. The use of routinely-collected data allows large cross-sectional studies to be made at little or no expense. This is a major advantage over other forms of epidemiological study.

Hence the present survey study has been designed to know the prevalence of anemia in school going children of Waghodia village (GJ) as a preliminary part of clinical study for doctoral research work.

\section{Methodology}

Cross sectional study: Total 500 children from the rural area of Waghodia village from primarysecondary health school were surveyed. Present survey conducted in between February 2020 to March 2020.

\section{Method of Collection of Data \\ Study Design}

A Cross sectional study was carried during February 2020 to March 2020, involving 500 children of either sex of two government schools of Waghodia village, rural area in Vadodara district, Gujarat; after obtaining consent from parents and head of the school.

\section{Sample Size}

Sample size was calculated using the formula $\{(1.96) 2 \times \mathrm{P} \times(1-\mathrm{P})\} /(0.05)$ considering the prevalence of anaemia as $50 \%$, and $95 \%$ confidence interval, the target sample size was 384 . Considering non-response rate as $20 \%$, the sample size was 461 ; more than required number was taken to minimize the permissible errors, and hence round up 500 children were screened.

\section{Ethical Approval}

Institutional ethical approval was obtained for the study, consent from parent of each child and school authority was obtained in prescribed format which was also approved by ethical committee.

\section{Collection of Data}

A specially designed Survey study case record form was prepared and validated through authorities was used to obtain relevant demographic and socioeconomic data. Age of each child was collected from date of birth enrolled in school register provided by the school authorities.A survey proforma was filled after obtaining required data from the parents of children below 10 years of age to ensure the accuracy of data.

\section{Blood Sample Collection}

Peripheral blood was collected $(5 \mathrm{ml})$, under aseptic precautions in tubes containing ethylene diamine tetra acetic acid (EDTA) at a final concentration of $1 \mathrm{mg} / \mathrm{ml}$. Blood cells were counted at the Institutional hospital laboratory using semi automated analyzer 3-Part Medonic M20 (Differential Cell Counter - 3-Part: Medonic M16/M20 - Sweden). The blood was well mixed and placed on a rack in the analyser.The instrument counted the number and type of different cells within the blood and the results of haemoglobin $(\mathrm{Hb})$, red blood cell (RBC), and hematocrit (HCT), mean corpuscular volume (MCV), mean corpuscular haemoglobin $(\mathrm{MCH})$, and mean corpuscular haemoglobin concentration (MCHC), white blood cell (WBC), granulocyte, lymphocyte, and monocytes were noted. Adequate quality control measures were taken in each test procedure to ensure the reliability of the results.

Children having $\mathrm{Hb}<11.5 \mathrm{gm} / \mathrm{dl}$ are considered as anaemic and graded as mild anaemia $\mathrm{Hb} 11$ $11.4 \mathrm{gm} / \mathrm{dl}$, moderate anaemia $8-10.9 \mathrm{gm} / \mathrm{dl}$ and severe anaemia $\mathrm{Hb}<8 \mathrm{gm} / \mathrm{dl}$ as per WHO guidelines ()

A team of 4 consultants and Post graduates scholars of Kaumarabhritya (Paediatric) department conducted the clinical examination of the school children to assess the health status including the anthropometry.

Statistical Analysis: Anemia was defined as $\mathrm{Hb}$ concentration $<11 \mathrm{~g} / \mathrm{dL}$ for children aged between 6 and 59 months while $<11.5 \mathrm{~g} / \mathrm{dL}$ for children aged between 5 and 11 years and $<12 \mathrm{~g} / \mathrm{dL}$ for children aged 12 years according to WHO. Further, Normal reference ranges used for hematological indicators (red blood indices and white blood indices) are provided in Table $2[10,11]$. Data obtained were recorded in Microsoft Excel 2007 and all statistical analyses were performed with GraphPad Prism software (version4.00). SPSS for Windows version 17.0, Chicago, USA, was also used for data analysis. Descriptive characteristics (mean and standard deviation) and percentage were performed for each parameter separately. Chi-square and independent $t$-test were used for proportions and mean comparisons between groups, respectively. Pearson's correlation tests were performed to examine the relationships between haematological indicators. The strength of association is measured by unadjusted odds ratio (OR) and 95\%confidence interval (CI). 


\section{Observations and Results}

Table No.1: Comparison of degree of Anemia with different religion and gender in different age group

\begin{tabular}{|c|c|c|c|c|c|c|c|c|c|}
\hline $\begin{array}{l}\text { Age group } \\
\text { of children }\end{array}$ & Gender & Frequency & Percent & Religion & Frequency & Percent & Anemia & Frequency & Percent \\
\hline \multirow{4}{*}{6 to 8 years } & Male & 54 & 79.4 & Hindu & 54 & 79.4 & Normal & 13 & 19.1 \\
\hline & Female & 14 & 20.6 & Muslim & 14 & 20.6 & Mild & 49 & 72.1 \\
\hline & \multirow{2}{*}{ Total } & \multirow{2}{*}{68} & \multirow{2}{*}{100.0} & \multirow{2}{*}{ Total } & \multirow{2}{*}{68} & \multirow{2}{*}{100.0} & Moderate & 6 & 8.8 \\
\hline & & & & & & & Total & 68 & 100.0 \\
\hline \multirow{4}{*}{9 to 11 years } & Male & 266 & 70.9 & Hindu & 311 & 82.9 & Normal & 79 & 21.1 \\
\hline & Female & 109 & 29.1 & Muslim & 64 & 17.1 & Mild & 280 & 74.7 \\
\hline & \multirow{2}{*}{ Total } & \multirow{2}{*}{375} & \multirow{2}{*}{100.0} & \multirow{2}{*}{ Total } & \multirow{2}{*}{375} & \multirow{2}{*}{100.0} & Moderate & 16 & 4.3 \\
\hline & & & & & & & Total & 375 & 100.0 \\
\hline \multirow{4}{*}{$\begin{array}{c}12 \text { to } 14 \\
\text { years }\end{array}$} & Male & 57 & 100.0 & Hindu & 49 & 86.0 & Normal & 11 & 19.3 \\
\hline & Female & 0 & 0 & Muslim & 8 & 14.0 & Mild & 45 & 78.9 \\
\hline & \multirow{2}{*}{ Total } & \multirow{2}{*}{57} & \multirow{2}{*}{100.0} & \multirow{2}{*}{ Total } & \multirow{2}{*}{57} & \multirow{2}{*}{100.0} & Moderate & 1 & 1.8 \\
\hline & & & & & & & Total & 57 & 100.0 \\
\hline
\end{tabular}

Table No. 2: Comparison of Hematological Indices in different age groups

\begin{tabular}{|c|c|c|c|c|c|c|c|c|}
\hline $\begin{array}{l}\text { Age group } \\
\text { of children }\end{array}$ & & $\mathbf{N}$ & Mean & Std. Deviation & Std. Error Mean & $\mathbf{t}$ & df & $\begin{array}{l}\text { Sig. (2- } \\
\text { tailed) }\end{array}$ \\
\hline \multirow{4}{*}{6 to 8 years } & PCV & 68 & 35.6765 & 2.17153 & 0.26334 & 135.478 & 67 & 0.000 \\
\hline & $\mathrm{MCV}$ & 68 & 69.2618 & 4.31461 & 0.52322 & 132.375 & 67 & 0.000 \\
\hline & $\mathrm{MCH}$ & 68 & 21.3735 & 1.20529 & 0.14616 & 146.231 & 67 & 0.000 \\
\hline & $\mathrm{MCHC}$ & 68 & 23.0559 & 2.03465 & 0.24674 & 93.443 & 67 & 0.000 \\
\hline \multirow{4}{*}{9 to 11 years } & PCV & 375 & 36.0373 & 2.37726 & 0.12276 & 293.556 & 374 & 0.000 \\
\hline & $\mathrm{MCV}$ & 375 & 68.8296 & 4.41037 & 0.22775 & 302.215 & 374 & 0.000 \\
\hline & $\mathrm{MCH}$ & 375 & 21.4261 & 1.15481 & 0.05963 & 359.292 & 374 & 0.000 \\
\hline & $\mathrm{MCHC}$ & 375 & 23.0312 & 1.84687 & 0.09537 & 241.488 & 374 & 0.000 \\
\hline \multirow{4}{*}{$\begin{array}{l}12 \text { to } 14 \\
\text { years }\end{array}$} & PCV & 57 & 35.6719 & 2.26367 & 0.29983 & 118.974 & 56 & 0.000 \\
\hline & $\mathrm{MCV}$ & 57 & 68.8456 & 4.67406 & 0.61909 & 111.204 & 56 & 0.000 \\
\hline & $\mathrm{MCH}$ & 57 & 21.5123 & 1.15636 & 0.15316 & 140.453 & 56 & 0.000 \\
\hline & $\mathrm{MCHC}$ & 57 & 22.9158 & 1.57897 & 0.20914 & 109.572 & 56 & 0.000 \\
\hline
\end{tabular}

\section{Statistical Analysis of Data}

Comparison of Gradation of Anemia with $\mathrm{Hb}$ percentage and age of child and gender of child

$\begin{array}{ccc}\text { Anemia Gradation as per WHO } & \mathbf{N} & \text { Hemoglobin gm/dl } \\ \text { Normal } & 103 & 12.6 \pm 0.54 \\ \text { Mild } & 374 & 11.01 \pm 0.58 \\ \text { Moderate } & 23 & 9.11 \pm 0.3\end{array}$

Average range of hemoglobin in normal child was observed to be $12.6 \pm 0.54$. In Mild anaemic child it was observed $11.01 \pm 0.58$ while in moderately anaemic child it was observed to be $9.11 \pm 0.3$. It means maximum number children having mild anaemia with range of $11.01 \pm 0.58$ range of $\mathrm{Hb}$.

Table 3: Percentage of Children in particular age groups on the basis of Anemia gradation - analyzed with chi square test

\begin{tabular}{|c|c|c|c|c|}
\hline $\begin{array}{c}\text { Anaemia } \\
\text { Gradation }\end{array}$ & Age of Child & Frequency & Percent & $P$ value \\
\hline \multirow{4}{*}{ Normal } & 6 to 8 years & 13 & 12.6 & $>0.05(\mathrm{NS})$ \\
\hline & 9 to 11 years & 79 & 76.7 & $>0.05(\mathrm{NS})$ \\
\hline & 12 to 14 years & 11 & 10.7 & $>0.05(\mathrm{NS})$ \\
\hline & Total & 103 & 100.0 & $>0.05(\mathrm{NS})$ \\
\hline \multirow{4}{*}{ Mild } & 6 to 8 years & 49 & 13.1 & $>0.05(\mathrm{NS})$ \\
\hline & 9 to 11 years & 280 & 74.9 & $>0.05(\mathrm{NS})$ \\
\hline & 12 to 14 years & 45 & 12.0 & $>0.05(\mathrm{NS})$ \\
\hline & Total & 374 & 100.0 & $>0.05(\mathrm{NS})$ \\
\hline \multirow{4}{*}{ Moderate } & 6 to 8 years & 6 & 26.1 & $>0.05(\mathrm{NS})$ \\
\hline & 9 to 11 years & 16 & 69.6 & $>0.05(\mathrm{NS})$ \\
\hline & 12 to 14 years & 1 & 4.3 & $>0.05(\mathrm{NS})$ \\
\hline & Total & 23 & 100.0 & $>0.05(\mathrm{NS})$ \\
\hline
\end{tabular}

The percentage of Normal, moderate and mild anemia in different age group was found no significant during the comparison. Mild Anemia is observed 13.1\%, 74.9\% and 12\%; in age between 6-8 year age group, 9-11 year age group and 12-14 year age group respectively. 
Aboli Patil et.al., Enormity of Iron deficiency anaemia in school going children in Gujarat, India

Table 4: Prevalence of Anemia as per WHO gradation in different age groups - Chi Square

Anaemia Gradation

AGE OF CHILD

FREQUENCY

PERCENT

$P$ value

Normal

6 to 8 years

13
79

9 to 11 years

12 to 14 years

$2.6 \%$

$>0.0 .5(\mathrm{NS})$

Mild

6 to 8 years

9 to 11 years

12 to 14 years

Moderate

6 to 8 years

9 to 11 years

12 to 14 years

Total

500

1

49

49
280

280
45

$15.8 \%$

$2.2 \%$

$9.8 \%$

$>0.0 .5(\mathrm{NS})$

9\%

$1.2 \%$

$3.2 \%$

16

$100 \%$

$0.2 \%$

$>0.0 .5(\mathrm{NS})$

$>0.0 .5(\mathrm{NS})$

$>0.0 .5(\mathrm{NS})$

$>0.0 .5$ (NS)

$>0.0 .5(\mathrm{NS})$

$>0.0 .5(\mathrm{NS})$

$>0.0 .5(\mathrm{NS})$

From above table it is clear that $20.6 \%$ children are having normal or above normal hemoglobin as per WHO classification of anemia; $74.8 \%$ children are having mild anemia and $4.6 \%$ children are having moderate anemia. In all 79.4\% (74.8 + 4.6) of children have anemia. It shows the escalating magnitude of prevalence of IDA in rural Gujarat. Prevalence is more in age group of $9-11$ age children $(56 \%)$.

Table 5: Chi Sqaure Test Analysis

\begin{tabular}{|c|c|c|c|c|c|c|c|}
\hline & \multicolumn{3}{|c|}{ Anaemia Gradation Acc WHO } & \multirow[t]{2}{*}{ Total } & \multirow[t]{2}{*}{$\mathbf{P}$} \\
\hline & & & Normal & Mild & Moderate & & \\
\hline \multirow{8}{*}{$\begin{array}{l}\text { Gender of } \\
\text { Children }\end{array}$} & \multirow{4}{*}{ Male } & Count & 58 & 305 & 14 & 377 & \\
\hline & & $\%$ within Gender of Children & $15.4 \%$ & $80.9 \%$ & $3.7 \%$ & $100.0 \%$ & $0.000(\mathrm{~S})$ \\
\hline & & $\%$ within Anaemia Gradation Acc WHO & $56.3 \%$ & $81.6 \%$ & $60.9 \%$ & $75.4 \%$ & $0.000(\mathrm{~S})$ \\
\hline & & $\%$ of Total & $11.6 \%$ & $61.0 \%$ & $2.8 \%$ & $75.4 \%$ & $0.000(\mathrm{~S})$ \\
\hline & \multirow{4}{*}{ Female } & Count & 45 & 69 & 9 & 123 & \\
\hline & & $\%$ within Gender of Children & $36.6 \%$ & $56.1 \%$ & $7.3 \%$ & $100.0 \%$ & $0.000(\mathrm{~S})$ \\
\hline & & $\%$ within Anaemia Gradation Acc WHO & $43.7 \%$ & $18.4 \%$ & $39.1 \%$ & $24.6 \%$ & $0.000(\mathrm{~S})$ \\
\hline & & $\%$ of Total & $9.0 \%$ & $13.8 \%$ & $1.8 \%$ & $24.6 \%$ & $0.000(\mathrm{~S})$ \\
\hline \multirow{4}{*}{\multicolumn{2}{|c|}{ Total }} & Count & 103 & 374 & 23 & 500 & \\
\hline & & $\%$ within Gender of Children & $20.6 \%$ & $74.8 \%$ & $4.6 \%$ & $100.0 \%$ & $0.000(\mathrm{~S})$ \\
\hline & & $\%$ within Anaemia Gradation Acc WHO & $100.0 \%$ & $100.0 \%$ & $100.0 \%$ & $100.0 \%$ & $0.000(\mathrm{~S})$ \\
\hline & & $\%$ of Total & $20.6 \%$ & $74.8 \%$ & $4.6 \%$ & $100.0 \%$ & $0.000(\mathrm{~S})$ \\
\hline
\end{tabular}

There is statistical significant correlation found between the gender and gradation of anemia in present study. More prevalence in male (83.7\%) compare to female (63.4\%) shows statistical significant correlation (P-0.000) with the WHO anemia gradation with gender.

Table 6: Pearson's correlation of hematological indices with each other in different categories of WHO classification of Anemia

\begin{tabular}{|c|c|c|c|c|c|c|}
\hline $\begin{array}{c}\text { Anaemia Gradation } \\
\text { Acc WHO }\end{array}$ & Parameters & Haemoglobin gm/dl & PCV & MCV & МСН & МСНС \\
\hline \multirow{5}{*}{ Normal } & Haemoglobin gm/dl & 1 & & & & \\
\hline & PCV & $0.227^{*}$ & 1 & & & \\
\hline & $\mathrm{MCV}$ & 0.016 & -0.189 & 1 & & \\
\hline & $\mathrm{MCH}$ & -0.095 & -0.129 & 0.012 & 1 & \\
\hline & $\mathrm{MCHC}$ & -0.101 & -0.133 & -0.115 & 0.133 & 1 \\
\hline \multirow{5}{*}{ Mild } & Haemoglobin gm/dl & 1 & & & & \\
\hline & PCV & 0.024 & 1 & & & \\
\hline & $\mathrm{MCV}$ & -0.031 & 0.068 & 1 & & \\
\hline & $\mathrm{MCH}$ & 0.034 & 0.040 & 0.043 & 1 & \\
\hline & $\mathrm{MCHC}$ & $0.119^{*}$ & -0.001 & -0.006 & 0.043 & 1 \\
\hline \multirow{5}{*}{ Moderate } & Haemoglobin gm/dl & 1 & & & & \\
\hline & PCV & 0.306 & 1 & & & \\
\hline & $\mathrm{MCV}$ & $0.430^{*}$ & 0.357 & 1 & & \\
\hline & $\mathrm{MCH}$ & -0.145 & 0.291 & 0.186 & 1 & \\
\hline & $\mathrm{MCHC}$ & 0.160 & 0.070 & -0.191 & 0.103 & 1 \\
\hline
\end{tabular}

$\mathrm{Hb}$ and PCV were found to be weakly positively correlated, at normal. Mild and moderate anemic patients $\mathrm{r}$ $(103)=0.227, \mathrm{p}<0.05 ; \mathrm{r}(374)=0.024, \mathrm{p}>0.05 ; \mathrm{r}(23)=0.306, \mathrm{p}>0.05$ respectively.

$\mathrm{Hb}$ and $\mathrm{MCV}$ were found to be weakly positively, weakly negatively and moderately positively correlated, at normal. Mild and moderate anemic patients $\mathrm{r}(103)=0.016, \mathrm{p}>0.05 ; \mathrm{r}(374)=-0.031, \mathrm{p}>0.05 ; \mathrm{r}(23)=0.4, \mathrm{p}<0.05$ respectively.

$\mathrm{Hb}$ and $\mathrm{MCH}$ were found to be weakly negatively, weakly positively and weakly negatively correlated, at normal. Mild and moderate anemic patients $\mathrm{r}(103)=-0.095, \mathrm{p}>0.05 ; \mathrm{r}(374)=0.34, \mathrm{p}>0.05 ; \mathrm{r}(23)=-0.145, \mathrm{p}>$ 0.05 . 
International Journal of Ayurvedic Medicine, Vol 12 (4), 833-838

Table 7: Pearson's correlation of hematological indices with each other in different age groups

\begin{tabular}{|c|c|c|c|c|c|c|}
\hline Age of Child & Parameters & Haemoglobin gm/dl & PCV & MCV & МСН & МCHC \\
\hline \multirow{5}{*}{6 to 8 years } & Haemoglobin gm/dl & 1 & & & & \\
\hline & PCV & -0.139 & 1 & & & \\
\hline & $\mathrm{MCV}$ & 0.032 & -0.037 & 1 & & \\
\hline & $\mathrm{MCH}$ & -0.103 & 0.026 & 0.137 & 1 & \\
\hline & $\mathrm{MCHC}$ & 0.020 & 0.076 & -0.156 & -0.050 & 1 \\
\hline \multirow{5}{*}{9 to 11 years } & Haemoglobin gm/dl & 1 & & & & \\
\hline & $\mathrm{PCV}$ & $.108^{*}$ & 1 & & & \\
\hline & $\mathrm{MCV}$ & 0.080 & 0.031 & 1 & & \\
\hline & $\mathrm{MCH}$ & -0.083 & -0.024 & -0.004 & 1 & \\
\hline & $\mathrm{MCHC}$ & 0.023 & -0.070 & -0.017 & $.110^{*}$ & 1 \\
\hline \multirow{5}{*}{$\begin{array}{c}12 \text { to } 14 \\
\text { years }\end{array}$} & Haemoglobin gm/dl & 1 & & & & \\
\hline & PCV & 0.111 & 1 & & & \\
\hline & $\mathrm{MCV}$ & 0.058 & 0.208 & 1 & & \\
\hline & $\mathrm{MCH}$ & -0.019 & 0.107 & 0.207 & 1 & \\
\hline & $\mathrm{MCHC}$ & 0.153 & 0.169 & 0.011 & -0.161 & 1 \\
\hline
\end{tabular}

Pearson's $r$ data analyses revealed a moderate negative correlation, $r=$ Statistical significance level $(p=0.001)$.

\section{Discussion}

The present study attempted to assess the association of haematological indices with the prevalence of anemia among children in the rural surroundings of Vadodara city, Gujarat India.

The mean $\mathrm{Hb}$ among school age boys was significantly lower than girls. Sahu et al. also found a lower mean $\mathrm{Hb}$ level in school age boys than girls in their research study(4). The prevalence of anaemia among preschool children was $52.5 \%$, which is much less when compared to the state data of $92.4 \%(5)$. The type of anemia among school age children was $69.4 \%$ (mild 64.8\%, moderate $4.6 \%$ ). Girls were significantly more anemic than boys in the age group of 12-14 years while more boys were anemic in the age group of 09-11 years. Similar results were reported for school children in Bangalore where prevalence of anemia was higher in boys aged 10 years whereas it was high in girls aged 11 years (6).The mean HCT,MCV, andMCH of school age boys were significantly lower than girls. Zemel et al() observed a significantly lower HCT among boys than girls of school age sickle cell children (excluding children receiving transfusion therapy). In this study chronic under nutrition (stunting)maybe one of the factors for lower level of HCT. Kokore et al.found that MCV and $\mathrm{MCH}$ are statistically higher for girls than their male counterparts aged 5-11 years. The hypochromasia ( $\mathrm{MCH}$ deficient) and microcytosis (MCV deficient) in school age population are higher in boys than in girls. The disruption of erythrocyte parameters like MCV andMCH precedes the final stage of anaemia with concurrent falling $\mathrm{Hb}$ levels below the limit. In this study, decrease in MCV and $\mathrm{MCH}$ might indicate a deficiency in micronutrients including iron and vitamins as suggested earlier (8). Mean MCV and $\mathrm{MCH}$ were significantly higher among school age girls than preschool girls. Moreover, $\mathrm{MCH}$ and MCHC of preschool children were low compared to schoolchildren. Similar findings were observed among girls of different age groups. Several studies reported an increase in mean MCHand MCHC levels with increase in age.

$\mathrm{Hb}$ was positively correlated with $\mathrm{RBC}, \mathrm{HCT}$, $\mathrm{MCV}, \mathrm{MCH}$, and monocyte in this population. At birth, the total $\mathrm{Hb}$ level, $\mathrm{RBC}$, and $\mathrm{HCT}$ are shown to be higher than at any other period of life (9). The $\mathrm{Hb}$ content and the RBCs then gradually rise to adult levels by the age of puberty (10). Maude et al.(11) even also found $\mathrm{RBC}$ correlated positively with total $\mathrm{Hb}$ in homozygous sickle cell patients where there is abnormal synthesis of $\mathrm{Hb}$. It was established that the $\mathrm{HCT}$ usually correlates well with $\mathrm{Hb}$ but is even less sensitive for iron deficiency than $\mathrm{Hb}$ (12). The positive association between $\mathrm{Hb}$ and $\mathrm{MCV}$ suggests a lesser chance of macrocytic anemia in the study population as the concentration of $\mathrm{Hb}$ varies concomitantly with cell volume. When RBCs divide in the bone marrow compartment, the resultant two daughter cells after each division are slightly smaller than the parent cell.The reduction in the number of such division's results in the eventual erythrocytes being larger than usual or macrocytic, with a raised MCV leading to an overall reduction in cell division and in a reduction in $\mathrm{Hb}$ biosynthesis (13). Khan et al. found significant relationship between $\mathrm{Hb}$ and $\mathrm{MCH}$ in elderly Pakistani males. Under iron deficiency condition, formation ofHb is reduced resulting in a reduction of $\mathrm{MCH}$ (14).

RBC was associated with HCT and monocyte and inversely with $\mathrm{MCH}$. In anemia, a reduction of the $\mathrm{Hb}$ is usually accompanied by reduction in the $\mathrm{RBC}$ and HCT (15). It was revealed that venous HCT values correlated highly with circulating RBC volume (16). Under autologous experimental conditions, the presence of oxidative stressed erythrocytes in blood exacerbates cytokine production markedly and thus the activation status of human monocytes indicates a probable influence of oxidative stress in these children (17). In anemic condition a marked fall in RBC, Hb, and HCT and a parallel increase in theMCV and $\mathrm{MCH}$ were observed. HCT was positively correlated withMCV and monocyte. MCV was found to be associated with $\mathrm{MCH}$ and monocyte positively and negatively with the granulocyte.There is a strong association between MCV and $\mathrm{MCH}$ in iron deficiency and megaloblastic conditions (18).

In all, there is correlation of $\mathrm{Hb}$ with the other hematological indices in our study, which is classical diagnostic marker of IDA. 
Pearson's correlation test shows statistical significant correlation of $\mathrm{Hb}$ with $\mathrm{PCV}$ in 9 to 11 age group of children, but no specific statistical significant level in other age groups with any of the parameters, it suggest that there is no specific statistical significance of prevalence of IDA in specific age group it is equally prevailed among all school going children in our study.

Pearson's correlation test shows statistically significant correlation of $\mathrm{Hb}$ with $\mathrm{PCV}$ in normal gradation, statistically significant correlation of MCHC with $\mathrm{Hb}$ in mild anemia gradation while statistically significant correlation of $\mathrm{Hb}$ with $\mathrm{MCV}$ in moderate anemia gradation.

\section{Conclusion}

Anaemia is a one of the burning issue in the India. Childhood iron deficiency anaemia still continues to be a significant public health problem in children between 5-16 years. Total of 500children were studied in the age group of 5-16 years. $377(75 \%)$ were male children, $123(25 \%)$ were female children. The prevalence of anaemia in children of 6-12 years age was $77 \%$. The prevalence of anaemia in children belonging to lower socio economic status is more than higher socioeconomic status. Contrary to common findings the Male children had higher prevalence of anaemia in all socioeconomic classes in our study. Emphasis on the aggressive drive for the prevention and cure of anemia should be encouraged.

\section{Reference}

1. Worldwide prevalence of anemia 1993-2005 WHO global Database on anemia; results and discussion:7 Retrieved from http://whqlibdoc.who.int/ publications/ 2008/9789241596657_eng.pdf

2. De Maeyer, E.M., P. Dallman, J.M. Gurney, L. Hallberg et al. Preventing and controlling iron deficiency anemia through primary health care: A guide for health administrators and programme managers. Geneva: World Health Organization 1989.

3. WHO/UNU/UNICEF, Iron Deficiency Anaemia: Assessment, Prevention and Control, A Guide for Programme Managers, WHO, Geneva, Switzerland, 2001

4. Sahu T, N. C. Sahani, and L. Patnaik, Childhood anemia - a study in tribal area of Mohana block in Orissa, Indian Journal of Community Medicine, vol. 32, no. 1, pp. 4345,2007

5. National Nutrition Monitoring Bureau (NNMB), Prevalence of micronutrient deficiencies, NNMB Technical Report 22, National Institute of Nutrition, Indian Council of Medical Research, Hyderabad, India, 2003.
6. Muthayya S, P. Thankachan, M. B. Zimmermann et al., Low anemia prevalence in school-aged children in Bangalore, South India: possible effect of school health initiatives, European Journal of Clinical Nutrition, vol. 61, no. 7, pp. 865-869, 2007

7. Zemel BS, D. A. Kawchak, K. Ohene-Frempong, J. I. Schall, and V. A. Stallings, Effects of delayed pubertal development, nutritional status, and disease severity on longitudinal patterns of growth failure in children with sickle cell disease, Pediatric Research, vol. 61, no. 5, pp. 607-613, 2007

8. Shuchismita Behera and Gandham Bulliyya, Magnitude of Anemia and Hematological Predictors among Children under 12 Years in Odisha, India, Hindawi Publishing Corporation Anemia Volume 2016, Article ID 1729147, 10 pages

9. Burman D, "Haemoglobin levels in normal infants aged 3 to 24 months, and the effect of iron," Archives of Disease in Childhood, vol. 47, no. 252, pp. 261-271, 1972.

10. Taylor MRH, C. V. Holland, R. Spencer, J. F. Jackson, G. I. O'Connor, and J. R. O'Donnell, Haematological reference ranges for schoolchildren, Clinical and Laboratory Haematology, vol. 19, no. 1, pp. 1-15, 1997

11. Maude GH, R. J. Hayes, and G. R. Serjeant, The haematology of steady state homozygous sickle cell disease: interrelationships between haematological indices, British Journal of Haematology, vol. 66, no. 4, pp. 549-558, 1987

12. Biesalski HK and J. G. Erhardt, Diagnosis of nutritional anemia-laboratory assessment of iron status, in NutritionalAnemia, M. B. Zimmermann and K. Kraemer, Eds., pp. 37-43, Sight and Life Press, Basel, Switzerland, 2007

13. Weir DG and J. M. Scott, The biochemical basis of the neuropathy in cobalamin deficiency, Bailli`ere's Clinical Haematology, vol. 8, no. 3, pp. 479-497, 1995

14. Thompson B, Food-based approaches for combating iron deficiency, in Nutritional Anemia, M. B. Zimmermann and K. Kraemer, Eds., pp. 338-358, SIGHT and LIFE Press, Basel, Switzerland, 2007.

15. Bain BJ, A Beginner's Guide to Blood Cells: Haematological Findings in Health and Disease, Blackwell, London, UK, 2nd edition, 2003

16. Mock DM, E. F. Bell, G. L. Lankford, and J. A. Widness, Hematocrit correlates well with circulating red blood cell volume in very low birth weight infants, Pediatric Research, vol. 50, no. 4, pp. 525-531, 2001

17. Liese AM, M. Q. Siddiqi, J. H. Siegel, T. Denny, and Z. Spolarics, Augmented TNF- $\alpha$ and IL-10 production by primed human monocytes following interaction with oxidatively modified autologous erythrocytes, Journal of Leukocyte Biology, vol. 70, no. 2, pp. 289-296, 2001

18. Croft RF, A. M. Streeter, and B. J. O'neill, Red cell indices in megaloblastosis and iron deficiency, Pathology, vol. 6, no. 2, pp. 107-117, 1974. 